\title{
Max Martins: \\ palavra, imagem e pensamento
}

Daniele Pimentel

Luís Heleno Montoril del Castilo

Recebido em 20 mai 2012- Aprovado em 20 set 2012

\section{Resumo}

O presente artigo percorre a poesia moderna e contemporânea de Max Martins em duas partes. A primeira traz a leitura do poema visual "Man $\mathcal{E}$ woman", de Max Martins, numa perspectiva teórica ligada, sobretudo, ao ideograma e ao estudo da forma (Gestalt) estudada por Haroldo de Campos, Décio Pignatari e Julio Plaza, autores que postulam o diálogo entre poesia e imagem. "Man $\mathcal{E}$ woman" engendra o questionamento dos limites da palavra (verbo) e um "alargamento" do espaço gráfico do poema através da metalinguagem. Em sua segunda parte, tem-se uma leitura ensaística de poemas de Max Martins com o objetivo de estabelecer a relação entre palavra, imagem $e$ pensamento.

Palavras-chave: Max Martins; palavra; imagem; pensamento; 
O prazer do texto é semelhante a esse instante insustentável, impossivel, puramente romanesco, que o libertino degusta ao termo de uma maquinação ousada, mandando cortar a corda que o suspende, no momento em que goza. (Roland Barthes) ${ }^{1}$

2 O Grupo dos Novos é a denominação dada aos escritores, artistas e intelectuais reunidos em torno do Suplemento Literário do jornal Folha Norte, de Belém do Pará, editado por Haroldo Maranhão e organizado por Mário Faustino. Sobre o Grupo, conferir a obra de Marinilce Coelho (2005).

3 De acordo com as informações de Marinilce Coelho (2005, p.134-5), foi através de Robert Stock que os jovens poetas paraenses tiveram um contato com autores como Elliot, Pound, Elisabeth Bishop, Cummings, entre outros. Essa influência pode ser percebida com maior vigor nos poemas de Max Martins, que adota experimentações estéticas espaciais vindas de Cummings, além da técnica ideogrâmica de Pound.

\section{“UM LANCE DE MAX"}

A trajetória literária de Max Martins (1926-2009) começa em 1952 com seu livro O Estranho, considerado por Benedito Nunes (2000, p. 23) uma passagem para o modernismo, se comparado ao estilo parnasiano dos dez anos anteriores, de poemas publicados de forma caseira e restritos a um pequeno grupo de amigos. Tal assertiva é testemunhal e também crítica, desse que foi amigo e leitor atento não somente dos poemas de Max Martins como também de literatura brasileira. Sem dúvida, $O$ Estranho pode representar o início da maturidade poética de Max Martins.

Essa ruptura inicial está ligada a um projeto maior que seria engendrado em suas obras posteriores, em que o autor de "Não para consolar" alinha sua escrita poética às inovações vanguardistas do "Concretismo" e poesia moderna européia, representadas por Augusto de Campos, Décio Pignatari e Haroldo de Campos, além de Mallarmé, Ernest Fenollosa, Ezra Pound, Rainer Maria Rilke e T. S. Eliot. Ressalta-se, no entanto, que essas influências já transitavam no Grupo dos Novos ${ }^{2}$ em Belém, encabeçado por Francisco Paulo Mendes, Paulo Plínio Abreu, Haroldo Maranhão, Mário Faustino, além do próprio Max Martins.

Segundo Benedito Nunes (2000, p.23), Mário Faustino (19301962) se consolida como um mediador essencial entre a vanguarda concretista e as novas intenções estéticas dos intelectuais paraenses. Demarca-se, nesse sentido, o impacto do livro "O homem e sua hora", do referido poeta, na produção literária de Max, além do convívio com um poeta estadunidense chamado Robert Stock, que traduziu poemas de escritores de língua inglesa e possibilitou a circulação dessa poesia entre o "Grupo dos Novos".

Dessa forma, Max Martins tencionava desenvolver um projeto estético de adensamento experimental partindo das transformações artísticas do período pós década de 50. A partir desse momento é possível notar em sua poética um avanço no tocante à forma e ao conteúdo dos poemas que compõem, por exemplo, o livro Anti-retrato, de 1960. Para Benedito Nunes (1992, p.25), "foi nesse livro que a temática do amor carnal começou a tornar-se o centro da obra de Max, desde então ligada à ideia de poesia enquanto arte exigente e ao mesmo tempo exercício de vida". Além disso, é a partir desse livro que o erotismo ganha um corpo verbal de destaque influenciado pelos romances de D. H. Lawrence e Anaiis Nin e pela prosa vanguardista de Henry Miller, precursor da "Geração Beat" nos Estados Unidos. 
4 Idem, 2005, p.144.

5 A influência do "orientalismo" na escrita de Max pode estar ligada ao interesse de Haroldo Maranhão pelo "haikai", que divulgou em Belém a obra O haikai no Brasil. De acordo com Coelho (2005, p.193), “a fonte literária era o poeta Matsuó Bachô, que viveu no século XVI, visto pelo crítico como o maior construtor de haikais da literatura japonesa".

6 Não confundir com o sistema de saber e conhecimento sobre o Oriente por parte do Ocidente tão bem analisado por Edward Said, em Orientalismo...

Colchete da autora.
Por outro lado, como afirma Marinilce Coelho: "o convívio com Robert Stock e com a literatura inglesa acentuou nos integrantes do 'Grupo dos Novos' o interesse por autores estrangeiros e a tendência para um estilo de versos breves e uma linguagem incisiva" - (2005, p.135). Nesse ínterim, o "Suplemento Literário" da "Folha do Norte", dirigido por Haroldo Maranhão, ganhava espaço e relevância no contexto paraense, ao divulgar a crítica literária modernista e moderna, além de poetas internacionais traduzidos por Mário Faustino, Paulo Plínio Abreu e Ruy Barata. ${ }^{4}$ Ressalta-se, contudo, o encontro tardio da inteligência paraense com a arte vanguardista européia, a partir da divulgação de pinturas de Pablo Picasso, Salvador Dalí, entre outros. Esse impulso vanguardista alcançaria grande êxito poético nos livros seguintes de Max Martins, que experimenta processos de colagem cubista e o "ready-made" de Duchamp.

Dessa maneira, a "atualização" da literatura paraense proporcionava um diálogo constante com as produções literárias de outros estados brasileiros, já que o "Suplemento" da Folha se comunicava com centros importantes como o Rio de Janeiro e São Paulo. Nessa "virada", surge uma das vanguardas mais importantes do período, a "Poesia Concreta", tendo a frente Haroldo de Campos, Décio Pignatari e Augusto de Campos, admiradores, assim como Max, da estética de Malarmé, Cummings, Bashô e Ezra Pound.

Anos depois, a experiência verbal ou o "lance de dados" de Max Martins se adensaria nas obras seguintes: H'era (1971), O ovo filosófico (1975), ganhando um maior radicalismo em $O$ risco subscrito, de 1976. Esse radicalismo formal envolve um trabalho minucioso com a disposição das palavras na página, criando possibilidades espaciais harmonicamente alinhadas ao ideário da vanguarda concretista, interessada em fazer uma "desleitura" da tradição literária iniciada com "Un Coup de Dés" (1897), de Mallarmé, passando pela escrita ideogrâmica chinesa e a escrita poética zen budista. ${ }^{5}$ Benedito Nunes esclarece ainda que "para o lance de O OVO FILOSÓFICO [Max] apoiou-se num certo Orientalismo $^{6}$ - a sabedoria contemplativa Zen e a erótica hindu, hauridas no BHAGAVAD GITA, no TAO TE KING e nos textos de Suzuki".7 (1992, p.26)

A relação entre a poesia de Max com a escrita chinesa é constantemente evocada em seus livros posteriores, através do uso de ideogramas, a criação de haikais e o trabalho com a "renga". Esse trabalho poético se realiza em A fala entre Parênteses (1982), num diálogo poético entre ele e seu amigo Age de Carvalho, em que juntos eles constroem uma poética de "mão dupla", numa parceria apontada no subtítulo da obra: "Poema escrito com Age de Carvalho à moda da renga", sugerindo que a poesia de Max se aproxima do processo de composição coletiva dos haikais.

Segundo Paulo Leminski, em seu estudo sobre Bashô, "o haikai surgiu numa circunstância coletiva: o renga é uma cadeia 
de tercetos, produzida oralmente, de improviso, numa roda de poetas, cada terceto pegando o mote do anterior" (1983, p.44). De acordo com esta possibilidade de entendimento da poesia de Max, pode-se lembrar tanto dos artifícios que envolvem a escritura dos haikais, quanto de procedimentos de "tradução" da escrita ideográfica.

Chegando em Caminho de Marahu, de 1983, percebe-se na escrita de Max a síntese verbal em diversos haikais, aliada ao uso consciente do trabalho de espacialidade apregoado por Mallarmé em "Um lance de dados". O primeiro poema do livro, "Viagem", prepara o viajante-poeta pelos caminhos do "eu" que se perde diante do rio: "O rio que eu sou / não sei / ou me perdi". Nos poemas seguintes do livro Max estabelece uma relação mais íntima com a experiência Zen, ao escrever "Meditação para Bashô", em forma ideogrâmica. Em seguida, nos poemas "Os chamados do tigre”, “Ideograma para Blake" e “Um jardim zen”, o verbo poético torna-se carne, corroborando o pensamento de Benedito Nunes sobre Max Martins: "a carnalidade do mundo - o mundo feito carne como Verbo - eis a forma singular que toma desde os mais ousados poemas de $\mathrm{H}^{\prime}$ ERA à estreita relação entre sexualidade e linguagem". (1992, p.33) ${ }^{8}$

A relação da poesia do autor de "Man \& Woman" com o Zen-budismo e o Concretismo foi muito bem demarcada por Arthur Bogéa, em o ABC do magro poeta Max Martins (1992) e numa entrevista de Max Martins concedida ao jornalista Elias Pinto, o poeta reitera sua ligação com o Oriente.

numa certa fase da minha vida fui despertando em mim um grande interesse pelo Oriente, que continua até hoje. A descoberta do Zen-budismo, por exemplo, me fascinou, foi um dos grandes prazeres que eu tive na minha vida de leitor. Mas eu não sou Zen-budista, não estou ligado a nenhuma religião. Eu me afasto na medida do possível, do que é institucionalizado. Não pertenço a academias de letras, a igrejas, a clubes ou partidos políticos [...].

Nos últimos poemas do livro, Max se identifica com a experiência visual concretista, ao construir cinco poemas espaciais em que se unem a técnica do ideograma, a teoria da forma (Gestalt) e o orientalismo zen-budista. Entre esses poemas, "Man \& woman" é o que se alinha aos princípios estéticos presentes no Plano-piloto

8 Nos referidos poemas de Max há uma clara menção ao poema "O Tigre", de William Blake, poeta inglês influenciado pelo pensamento oriental, e autor do livro clássico "O Casamento do Céu e do Inferno". da Poesia Concreta, de 1955, que propunha um diálogo intenso entre verbo, som e imagem, cunhados no termo "verbivocovisual".

\section{O VERBO EM CÓPULAS}

A experiência da Poesia Concreta é o resultado de uma maturação artística. Augusto de Campos, Décio Pignatari e Haroldo de Campos propunham, a partir do lema de Oswald de Andrade ("fazer uma literatura de exportação"), romper com a temática nacional no contexto da criação poética, no sentido de criar uma 
9 Segundo esse paideu$m a$, é possível antever diversos níveis de poetas, de acordo com o talento individual para criar possibilidades de ver o fenômeno poético a partir de prismas inovadores. Dividiram-se então os poetas, segundo Campos (2006, p.10), em inventores (artistas que criaram formas inovadoras de trabalhar com a palavra), os mestres (artistas que tomaram a lição dos primeiros e conseguem ou não criar poesias criativas) e os diluidores (artistas que não conseguem criar um trabalho consistente no nível da palavra).

10 Pignatari (1987, p.49) explica que "os ideogramas correm diante dos olhos do leitor como fotos ou fotogramas de um filme. Isto já não ocorre com a escrita ocidental corrente: você precisa primeiro mentalizar as palavras e ligá-las por contiguidade a coisas e fatos - para poder saber o que elas significam.

11 A segunda parte desse artigo propõe a leitura desse processo verbal-imagem-conceito.

${ }^{12}$ Um estudo fundamental sobre o a técnica do ideograma está no livro "Ideograma: Lógica, Poesia, Linguagem" (2000), organizado por Haroldo de Campos.

13 MARTINS, 1992, p.133. arte literária que pudesse se posicionar de forma diferente em relação ao cânone europeu e norte-americano. Assim lançaram mão do "paideuma", expressão criada pelo poeta estadunidense Ezra Pound. ${ }^{9}$

Os concretistas criaram "vetores" que nortearam a criação do grupo intitulado de "Noigandres". Segundo Campos, a poesia concreta é o "produto de uma evolução crítica de formas dando por encerrado o ciclo histórico do verso (unidade ritmo-formal)" (2004, p.24). Assim, eles visavam criar inúmeras possibilidades de palavras no espaço em branco da página, indo além dos "caligramas" de Apollinaire. ${ }^{10}$ A construção da imagem poética tinha que buscar uma trama visual mais próxima dos ideogramas japoneses, ou seja, a ideia central era partir do nível verbal, entrar no plano da imagem, até chegar a um "conceito"11. Desse modo, o caráter icônico do poema não poderia simplesmente materializar algo do mundo visível, mas recriá-lo enquanto metáfora. ${ }^{12}$

A partir do contato e do interesse de Max Martins pela escrita chinesa e pelas experimentações da poesia concreta paulista, ele "caminha" na busca de uma escrita poética visual. Sem ater-se às representações comuns da forma poética, o poema transformar-se-á em imagem composta pela palavra concreta, como se pode visualizar em "Man \& woman". Poema que suscita diversas interpretações, a mais corrente é a do ato erótico. Mas é no plano da construção e criação poética que o poema revela o alto poder de síntese da metáfora.

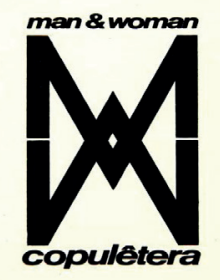

Fig 1: "Man \& woman" - Max Martins ${ }^{13}$

De início é evidente que o poema sugere a "insinuação" do ato sexual, em que os pólos (masculino e feminino) interligam-se através dos termos em inglês "Man" e "Woman", numa possível ligação ao signo linguístico "copulêtera", disposto abaixo do título. Por outro lado, este neologismo [copulêtera] atinge sua máxima literalidade ao sugerir que os dois sujeitos, ou letras, encontram-se "copulados". Como observa Roland Barthes em "O prazer do texto" (1987, p.30): "o escritor de prazer (e seu leitor) aceita a letra; renunciando à fruição, tem o direito e o poder de dizê-la: a letra é seu prazer". Nesse sentido, os signos visuais, entrelaçados, representam uma dimensão erótica e metalinguística ("crítica do próprio ato de escrever"), ao propor a união entre as letras " $\mathrm{M}$ " e "W", criando, dessa maneira, uma síntese (homem/mulher - 
metáforas do corpo da palavra), uma vez que o signo [Man] está inserido em $\mathrm{Wo}[\mathrm{man}]$ em forma de um anagrama, projetando um "duplo" reflexo que converge numa simetria geométrica.

Haroldo de Campos, citando Umberto Eco, diz que "a mensagem reveste uma função estética quando apresenta estruturada de maneira ambígua e se mostra auto-reflexiva, isto é, quando chama a atenção do destinatário antes de tudo sobre a própria forma dessa mensagem" (1977, p.146). Essa afirmação é corroborada pela inovação estético-visual de "Man \& woman", que pensa e repensa o ato de escrever (poiésis - fabricar), diante do processo criativo. A partir das possibilidades de visualização do poema, cria-se um alinhamento com a técnica cubista marcada pela "desmobilização" do "olho" frente ao produto artístico.

Teríamos ainda no título do poema ("Man \& woman"), dois fonemas que se [con]fundem " $\mathrm{M}^{\prime \prime} \mathrm{e}$ " $\mathrm{W}$ ", sendo uma consoante bilabial de sonoridade nasalada e outra vogal posterior arredondada. A sonoridade nasal da consoante se liga à ideia de respiração ofegante, dele e dela. Neste sentido, o ritmo presente no título do poema demarca a "pulsação de elementos simultâneos". Décio Pignatari (1987, p.20) afirma que o ritmo poético é ao mesmo tempo sonoro e icônico, conceito que pode ser aplicado ao esquema rítmico do texto visual de Max:

\section{Man \& Woman}

Note-se que o ritmo binário descendente sugere iconicamente um movimento contínuo ascendente [sílaba tônica] e descendente [sílaba átona], o que equivale dizer que, semioticamente, projeta-se a seguinte imagem, em que as pontas superiores são representações das sílabas átonas, e as inferiores indicam as átonas.

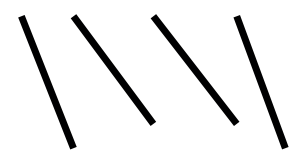

Essas dissonâncias fonéticas representam alternâncias em seus poderes de sugestão, em que o signo " $\mathrm{M}$ " estaria ligado à sinuosidade dos movimentos femininos, enquanto que "W" estaria vinculado ao desejo masculino, uma vez que o signo homem visualmente no poema se sobrepõe ao signo mulher. Noutro sentido, pode-se ainda definir que ambos se encontram num estado de harmonia, em que há a fusão das sensações ligadas ao prazer sexual e de mesma intensidade, ocasionando assim, pontos de equilíbrio representado pelo "yin-yang" oriental. Neste sentido, teríamos a erotização do verbo em "Man \& woman", sustentado naquilo que Barthes (1987, p.13) chama de "fluxo apressado de todos os prazeres da linguagem". 


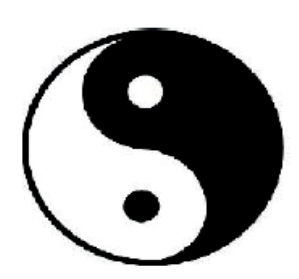

Fig 2: Símbolo chinês - ying-yang ${ }^{14}$

Segundo a cultura chinesa, o "yin-yang" corresponde, metaforicamente, aos elementos feminino/masculino, céu/terra, ou mesmo o "Alfa" e o "Ômega" da filosofia chinesa. No poema em estudo, os signos M[a]n/W[o]man estão associados ao "corpo da escritura" literária, ou mesmo ao "sopro" do verbo erótico primordial. Benedito Nunes (1992, p.34) confirma essa tese quando diz que a poesia de Max incorpora o "corpo único, feminilizado, de que as coisas são as zonas erógenas, e que tende a fundir num só espaço a diferença entre o interior e o exterior".

Por outro lado, se estabelecermos uma relação com o poema "Vogais", de Arthur Rimbaud, é possível notar na construção poética de "Man \& Woman" uma presença circular da criação do mundo, ligada ao sagrado. No poema de Rimbaud as letras ganham representações cromáticas: A (negro); E (branco); I (rubro); $\mathrm{U}$ (verde); $\mathrm{O}$ (azul). No texto de Max as vogais se distribuem da seguinte maneira: A-E-O-A. Se notarmos que segundo a simbologia oriental o "Yin-Yang" representa a relação harmônica entre o "Claro-Escuro", o esquema de letras iniciais corrobora essa relação: A (negro); E (branco). No entanto, a presença da letra $\mathrm{O}$ (azul) sugere o que na poética de Rimbaud significaria a ascensão, ou mesmo o [Ô] mega, fim de um ciclo e início de outro, pois a última vogal é novamente o princípio de tudo: A (alfa).

Quanto à forma, se observa o princípio "gestáltico" constituído pela recorrência "figura-fundo". A "Gestalt" utilizada na composição do poema se aproxima do "poemóbile", já que podemos visualizá-lo a partir de diversos ângulos. Isto é, poderíamos manipulá-lo como uma folha de papel, depois dobrá-lo ao meio, ou mesmo visualizá-lo na posição vertical e horizontal. Nesse sentido, o "tempo" no poema é sugerido a partir da "teoria da forma", pois as distribuições dos elementos visuais compõem duas forças que atuam no campo psicológico do leitor. No "Plano piloto da poesia concreta" a Gestalt é citada como um dos recursos da nova vanguarda brasileira.

${ }_{14}$ Plaza, 2008, p.181.

o poema concreto comunica a sua própria estrutura: estrutura-conteúdo.O poema concreto é um objeto em si por si mesmo, não é um intérprete de objetos exteriores e/ou sensações mais ou menos subjetivas. Seu material: a palavra (som, forma, visual, carga semântica). Seu problema: um problema de funções-relações desse material. Fatores de proximidade e semelhança, psicologia de gestalt (CAMPOS, 2004, p.24-25). 
O poema "Man \& woman" permite uma leitura a partir da ideia de "figura-fundo". No espelhamento imagético, num dado momento aquilo que é figura torna-se posteriormente em fundo, e para que a percepção de outros aspectos seja detectada, não é possível, segundo a Gestalt, deter-se simultaneamente na percepção da figura e do fundo, pois, cria-se a "ilusão" que ora destaca o plano escuro, ora o fundo claro.

De acordo com Júlio Plaza a "forma e significado são isomorfos como um signo de possibilidades" (2008, p.169). Assim, é possível "ler" o poema de Max Martins atentando para sua "mobilidade" estética e como "objeto" manipulável pelo leitor. Partindo dessa assertiva, a "gestalt" de "Man \& woman" sugere outros planos de elaboração visual, ao inverter o campo de visão. Os novos "produtos" estéticos de Max sofrem as radicalizações advindas das poéticas do concretismo, em que os poemas se transformam em objetos "desmontáveis". O exemplo disso é o "Poemóbile" "Rever", de Augusto de Campos, elaborado em folha de papel, em que se nota o mesmo processo de "espelhamento" das letras presentes no poema "Man \& woman".

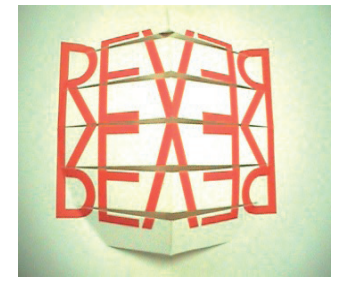

Fig 3: Poemóbile Rever - Augusto de Campos ${ }^{15}$

A "tradução" semiótica do signo verbal para o signo não-verbal se dá pela passagem dos primeiros signos escritos em inglês (man/woman) suscitados na posição superior do poema de Max. Deste modo, os elementos verbais estão diretamente conectados na transposição ideogrâmica que representam iconicamente as respectivas iniciais sígnicas das letras $\mathrm{Me} \mathrm{W}$; processo de inversão ou "aglutinação" em que verbo/imagem se fundem na "cópula" (fusão) das letras. Essa "transcriação" poética no poema de Max se aproxima do pensamento de Plaza, (2008, p. 164), quando ela afirma que na "transcriação de um poema para um signo visual, vemos que há transmutação dos objetos imediatos dos signos. Ao caráter descritivo da linguagem verbal, superpõe-se uma organização visual de qualidade sintética que permite, num só olhar, capturar a atividade sígnica pensamental".

Desse modo, a poética de Max assimila tendências visuais

${ }^{15}$ Disponível em: http://farm3.static. flickr.com/2329/ 2336364800_7d6f0cbc 47.jpg que dialogam intertextualmente com outros poemas concretos como, por exemplo, "Nascemorre" (1958) de Haroldo de Campos. Esse poema, semioticamente, projeta ícones que se aplicam na interpretação de "Man \& woman". Esquematicamente, Plaza (2008, p.104) estabelece o significado de dois ícones em forma triângulo. 


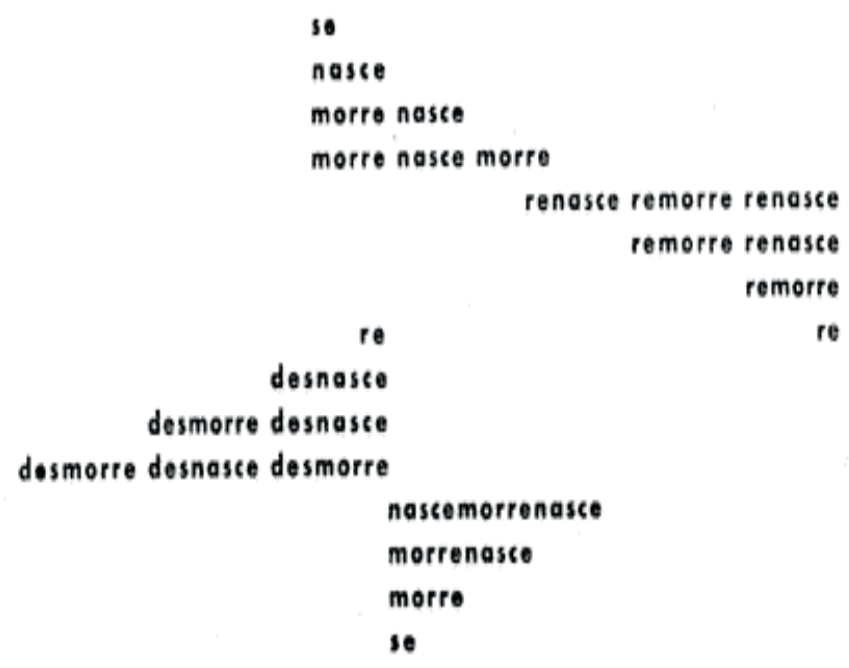

Fig 4: Poema Nascemorre - Haroldo de Campos ${ }^{16}$

NASCE $=\triangle$ Triângulo + branco $=$ símbolo da vida. Seu objeto imediato denota o equilíbrio dinâmico.

MORRE $=\nabla$ Triângulo invertido $=$ símbolo da morte. Seu objeto imediato denota equilíbrio estático; posição antagônica ao anterior.

Esses dois ícones estão presentes em "Man \& Woman", em dois ângulos. A representação dos dois triângulos se liga à "vida" e à "morte", num equilíbrio dinâmico, assim como o "yin-yang" dos chineses. Nessa visão, a união erótica das letras metaforiza o processo de criação poética, em que o artista busca equilibrar o verbo diante da página em branco, na procura da "palavra pura", na síntese do "Alfa" e do "Ômega". A visualidade erótica do poema de Max Martins significa o próprio corpo da escritura literária, como afirma Barthes: "o texto tem uma forma humana, é uma figura, um anagrama do corpo? Sim, mas de nosso corpo erótico" (1987, p.24).

A escritura poética de Max Martins demonstra uma maturidade estética ao nível do que Pound (2006, p.10) chamou de "Mestre" em seu conceito de "Paideuma": "artistas que tomaram a lição dos primeiros e conseguem ou não criar poesias criativas". Nesse caso, Max, poeta que se engendra no âmago das transformações estéticas do pós-guerra, demonstra uma abertura para os impulsos iniciados pelas vanguardas europeias, sem, no entanto, se abster do "sopro" de renovação literária que a literatura brasileira encetava a partir do grupo "Noigandres".

II

Ler Max e desdobrá-lo de e através de seus poemas é exercício necessário de quem tem o ofício de estudar poesia e ativar seus sentidos, sem os quais resta apenas o lugar do autor, suas obras e

${ }_{16}$ Plaza, 2008, p.100. sua institucionalização no corpus de escritores de Poesia Brasileira. 
Em "o desabitado segredo das palavras", um verso de Saltimbanco, de Max Martins, do livro de poemas Marahu poemas, de 1991, tem-se o enigma do "falso poema". Esse Saltimbanco que está fora do palco, na metade da cama, nessa zona de esquecimento, zona desabitada, do rito do ofício aponta para o lugar da poesia. Passar por esse lugar, nessa procura que é a da poesia, já aludida por Carlos Drummond de Andrade ${ }^{17}$ ainda atual, corrente e paradoxalmente desconhecida, é passar por esse espaço e tempo de existência e vida em linguagem poética.

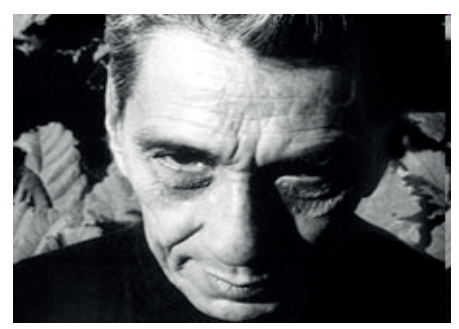

Fig 5: Max Martins, foto de Béla Borsodi

A imagem do poeta Max Martins, da foto de Béla Borsodi, pode servir para abrir o claro-escuro, a luz-sombra, de um olho que vê e outro que se esconde, dessa linguagem poética. Na foto, o olho que vê não o faz diretamente, e o que revela é o olhar oblíquo e falso do poeta. Do poeta, não de Max Martins. É um olhar de baixo para cima, como se levantado do chão, olhasse como se agisse, em suspenso, inconformado, não formado.

E não se vê o corpo, só o rosto, meio luz, meio sombra. Na luz do rosto, um vinco, um corte, um valo, uma lâmina: na face, na pálpebra, na fronte. E a cabeça, como um ovo. E o rosto com o ovo. E o ovo com um olho que vê: V. Entre olhos, no ovo.

Eis o achado da procura da poesia: o poema é um ovo. Para ver. Que se vê. Através do qual se vê. Logo, um olho. Olho oblíquo, olho cego, olho claro, olho escuro, dois olhos no poema. Desse que lê. Que ao ler, vê. Que ao ver, vê atravessado. Através: eis o que o poema oferece: um outro exercício de olhar, não diário, não cotidiano, não o mesmo, não o sempre mesmo. E se repete, é porque prepara o corte, a fenda, o risco. Entre dois olhos, dois olhares.

Eis “O ovo filosófico", de Max Martins: ${ }^{18}$

\footnotetext{
17 "Procura da Poesia" faz parte do livro de poemas intitulado, $A$ rosa do Povo, publicado pela primeira vez pela editora Livraria José Olympio Editora.

18 Todos os poemas transcritos foram extraídos de Não para consolar, 1992.
} 


\section{Um olho novo vê do ovo}

se

fora do foco

do ovo o olho

do ovo

é cego

fora dos fogos

do olho o ovo

do olho

é oco

como

do fundo do olho

extirpar o vago

escuro

e ser o ovo vendo?

no centro do ovo

fabricar a gala

clara

e ver o olho sendo?

- é como (ver) em mira

amorosa

o olho

rever (ter) em giro

geratriz

o ovo

ou

nos intertícios do ventre

(claro-escuro da página)

In

vol ver

o

ovo

obviar o olho

- indo e vindo -

ovante

(ovo e olho 
raiz e velo

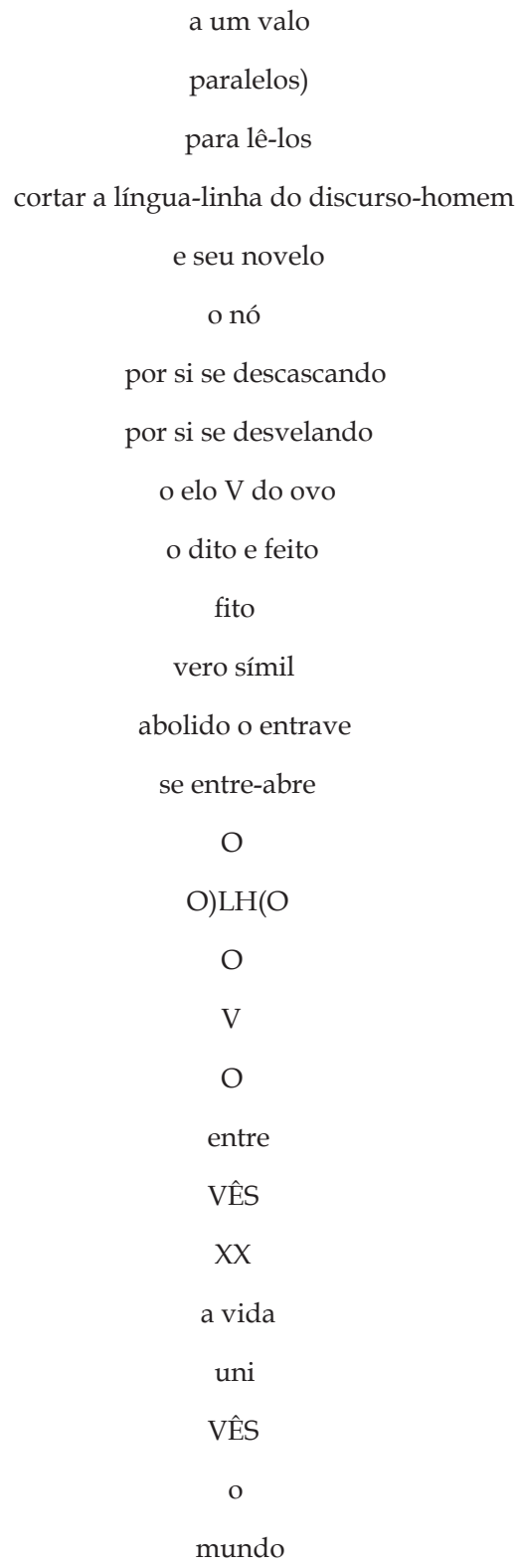

(de O Ovo Filosófico. Risco Subscrito, 1980, In:1992)

Na foto é possível ver o verso: “Como extirpar do fundo do olho, o vago escuro e ser o ovo vendo?". Verso que se cruza com a imagem projetada, com o olho de Max, com o olho da câmera mágica de Béla Borsodi. O vago escuro do fundo do olho vê entre parênteses, em mira. Tem-se um olho reverso, em movimento, indo e vindo, claro-escuro da imagem, no claro-escuro do poema.

No rosto do poeta tem-se o ovo e o olho em "risco subscrito", subentendido, subreptício, algo fraudulento, oblíquo. Para ler o poema é necessário prescindir da realidade mais superficial, 
ver através desse "ovo filosófico". Esse que está na fronte, que oferece o olho novo, o olho no ovo, que se situa no espaço aberto pela língua cortada do discurso descontínuo, outra língua, outro discurso, outra possibilidade de ver, de dizer, de sentir o mundo. Esse caminho possível "entre vês", desentravado.

Essa poética de "O Ovo Filosófico" estava latente. Em $O$ Estranho, livro de poemas de 1952, em "Poema", o novelo do discurso-homem, está delineando a vida do rito, no ritual, do ofício, das instituições, da memória que coagula o poema em estado vago. $\mathrm{E}$ a vaguidade do poema, sua morte contida na vida mundana, na língua cotidiana. O poeta-mundo é o falante homem-mundo-documento com todas as identidades registradas. E ainda o homem que responde à moral e à sensação de existência imediata das horas e do calor opressivo das vestes comunais. A nudez do poeta, seu cansaço e um tédio de viver produzem o poema do não-poema, o poema do poeta mudo, do homem-mundo, de "um olho com um vago escuro".

O vago escuro do olho, um olho vago, de um poema vago, sem a mira, já se anunciava em "Poema", em que Eu e mundo têm relações forçosas, em que o Eu pressente o poema que rola livre do mundo, de forte correlação drummondiana: ${ }^{19}$

\section{Poema}

Ocorre-me o poema.

Contudo há a religião,

A pátria, o calor.

Procuro ver na noite profunda

Quero esquecer no momento

Que sou o homem de vários documentos.

Forço.

Dói-me o calo desta vida "meu Deus!"...

Lavo as mãos.

Mas tenho de pôr a gravata,

E salvo a moral. Abano-me.

Rola o poema e o mundo.

E eu mudo.

${ }^{19}$ Sobre a trajetória de Max Martins, sua formação e suas influências literárias, conferir o já citado prefácio ao livro de poemas Não para consolar (1992). Ou ainda http://www.culturapara.com.br/maxmartins/ opiniao01.htm.

(O Estranho, 1952, In: 1992)

Em Anti-retrato, de 1960, em "Max, magro poeta", o poema ferve no ventre da mosca, o que lhe dá as asas, o voo. Mas o poeta é esse sem corpo, ou corpo magro, de uma forma em procura daquele olho-ovo, ovo-olho, olho novo, que desse o "sal dentro das pedras". O magro poeta é a mosca em cujo ventre ferve o poema-ovo. 
Max, magro poeta

Max, magro poeta

na paz dos prados de aquarela

acaso amaste o lírio

colhido às pressas

entre os sapatos?

Será que encontraste

em contraste com a flor

a ponta do punhal dentro da flor?

Procura no teu bolso a bússola

e a âncora no teu peito

deste barco prestes a partir

de tua garganta.

Na quilha enferrujada,

na popa ressequida

descobrirás a ilha

Magro poeta, o sol dos muros

ainda anotas

mas, e o sal que escorre

dentro das pedras?

Ao pouso inesperado duma asa

contempla a mosca:

no seu ventre ferve-lhe o poema.

(Anti-retrato, 1960, In: 1992)

O que em KOAN, de $H^{\prime} E R A, 1971$, é revelador sobre a procura desse ovo? KOÃ é palavra carregada de simbolismo verbal primitivo contido na concepção dualista da vida: Ã é a essência em tupi-guarani; KO é a existência. Tem-se aqui o invisível e visível; o distante e o próximo, relações entre a raiz e velo do "ovo filosófico". Como não dizer sobre os vincos, sulcos do rosto-olhoovo da imagem fotografada, quando diante dos versos "Cavo esta terra - busco num fosso / FODO-A"? Escavação da palavra.

O que também viera no poema desde fora para dentro, desde longe para perto, KOÃ, ekoãndo, eis mais uma vez "max" diminuído no nome pela minúscula inicial, o homem, o poeta ekoãndo, movimento de desaparecimento dessa personalidade do mundo, apagamento do sujeito. Seria sua morte? Eis a resposta: "cavo sou", após os espelhos turvarem-se, onde se projetam as faces familiares, a turvação da imagem no espelho, "ecoã" torna-se invisível, indizível, e "a pá nas mãos vazias" é o silêncio.

Como deixar de falar do olho-ovo de Koan? Se ele está no que é visível do que fala, o olho da boca, o $\mathrm{O}$, o olho do fosso, o olho osso, o olho do oco, do soo, do FODO Â, esse ato do sexo visível-invisível. 
Koan

A pá nas minhas mãos vazias

Não a pá de ser

mas a de estar, sendo pá

lavra no vento

nuvem-poema

arco

busco-te-em-mim dentro dum lago

$\max$

eKOÃdo

e a face ex-garça-se verdemusgo

muda

(Quem com ferro fere

o canto-chão

infere o

silen

cioso

poço?)

pá!

Cavo esta terra - busco num fosso

FODO-A

agudo osso

oco

flauta de barro

soo?

Silentes os sulcos se fecham

espelhos turvam-se

e cavo sou

a pá nas minhas mãos vazias

(H'ERA, 1971)

Tem-se aí uma certa escrita do "Risco subscrito", de 1986:

"a praia é um só ver desvendo".

Max tem escrito sobre um olho novo, esse ver desvendo. Aí está contido o sentido dos sujeitos e objetos da linguagem poética. Aprender uma língua que fala desde a infância do Eu e do Mundo, mas essa língua tornou-se muito comunicativa e pragmática. Retirar dela a praia subscrita é escavar a língua, fodê-la para além da imagem análoga direta. Um olho novo vê a praia desvendo-a, e a praia é verso.

Escrita

quem nos olha é só uma praia

quem nos ouve é só uma praia

quem nos é é só uma praia

e a praia é só um ver desvendo 
o desouvido deus-ouvir o som negado

E somos só esta vã escrita

nosso riso-risco contra um espelho, praia

que nos inverte e desescreve

dissolVENDO-NOS

(Risco subscrito, 1980)

\section{$\mathrm{O}$ risco de eros}

O olho novo também escreve o risco de eros. Em Poema $(O$ estranho, 1952) tem-se o INTERDITO, o poema impedido e a angústia plantada pela morte e o mal, morte do ser-pleno, ser-livre. No entanto temos o poema, esse poema-angústia do outro poema não escrito. Há um poema "interdito", entredito no poema realizado.

Interdito, angústia do poema, morte, mal, não são simples palavras recolhidas. Elas pertencem ao círculo de sentido do Erotismo. Um círculo traçado por Georges Bataille ao dizer: "o erotismo é a aprovação da vida até na morte" (O erotismo), ou em: "Sólo la larga agonía del poeta revela acaso, al final, la autenticidad de la poesia" (A literatura e o mal). O poema de Max carrega consigo a procura que se torna angústia, em que guarda o outro poema, esse de energia submersa e pleno de vida, mas morto.

Dois seres, dois poemas, em Poema, nos oferecem o movimento de continuidade-descontinuidade, dito por Bataille dessa maneira: "para nós que somos seres descontínuos, a morte tem o sentido da continuidade do ser".

Paradoxal condição própria de ser humano, o conhecimento do mundo e do erotismo implica uma experiência interdita e transgressora: religião, pátria, calor, homem de vários documentos, calejado (marcado). Deleuze e Guattari diriam estriado, pela vida interdita. E aqui: desse sacrifício, dessa violência e morte, vive o homem erótico, nele vive o erotismo, dessa experiência psíquica da angústia de desejo e não-realização, dele tem-se grande parte de tudo que se chama arte e poesia. O erotismo dos poemas de Max Martins é o roteiro libertino através do qual e no qual se tem a aprovação da vida na morte da humanidade extrema. Nesse sentido, o poema é o erotismo que triunfa sobre a interdição.

KOAN (H'era, 1971) participa desse roteiro e diz sobre movimento contínuo-descontínuo, de mão dupla do erotismo. $\tilde{\mathrm{A}}$ - essência do tupi-gurani, aglutinada à $\mathrm{KO}$ - existência, movimento do invisível (A) e do visível (KO), de distanciamento ( $\mathrm{A})$ e proximidade $(\mathrm{KO})$. E aqui o tônus erótico é o da palavra e da linguagem. Paradoxal condição essa do ser da linguagem erótica, traçar a linha de fuga como saída calculada. Ekoar é desaparecer para existir, max diminuído, sumido, mas vivo em palavra. Ekoãdo é o movimento de desaparecimento da personalidade 
do mundo, apagamento do sujeito, MORTE. Aí está o erotismo: "cavo sou" após os espelhos, onde se projetam as faces familiares, turvarem-se, turvação da imagem no espelho, "ecoa", tornar-se invisível, indizível, o silêncio: "a pá nas mãos vazias". Erotismo incrustado porque escavado, porque fodido na terra. Max-poetaeu morto para aprovar a vida.

Lembrar-se do olho? O olho erótico é o novo: "um olho novo vê do olho". Lord Auch ( pseudônimo de Bataille) tem uma história do olho.

Hacia muchísimo calor. Simona colocó el plato sobre un pequeno banco, se instaló delante de mí y, sin separar sus ojos de los míos, se sentó sobre él sin que yo pudiera ver cómo empapaba sus nalgas ardientes en la leche fresca. Me quedé delante de ella, inmóvil; la sangre subía a mi cabeza y mientras ella fijaba la vista en mi verga que, erecta, distendía mis pantalones, yo temblaba. (BATAILLE, 1994, p.33)

Simona había caído en un charco de lodo y se embarraba el cuerpo con furor: se masturbaba con la tierra y gozaba violentamente, golpeada por el aguacero, con mi cabeza abrazada entre sus piernas sucias de tierra, su rostro enterrado en el charco donde agitaba con brutalidad el culo de Marcela, que la tenía abrazada por detrás, tirando de su muslo para abrírselo con fuerza.

Empecé a escribir sin ninguna idea precisa, incitado sobre todo por el deseo de olvidar, por lo menos provisionalmente, mi identidad personal. Al principio creí que el personaje que narraba en primera persona no tenía ninguna conexión conmigo. (pp. 33-34)

Calor, terra, esquecimento de identidade pessoal, três expressões-chave para abrir o olho erótico do poema e liberar o ser invisível do olho, nesse espaço a alusão "fabricar a gala clara" não se liga ao erotismo somente pela imagem sexual, mas pela potência criadora investida no ato poético, o olho invisível é um "ânus solar" em que o interstício, as contra-movimentações, contra-direções, contra-dições, do claro-escuro, do vol-ver, indo e vindo, olho e ovo, raiz e velo, do ato sexual, dos sexos, ekoando no valo-rego. Essas movimentações cortam "a linha do discurso-homem", e estamos mais uma vez no ponto de origem do erotismo de Max e de que fala Bataille, perda de si para encontrar-se no caos e acaso da poesia maldita porque transgressora e de verdade simiesca: "vero simil". Há muito de primitivo nisso tudo, terreno, ctônico, mas, paradoxalmente, alado, desvelado, liberto. Finalmente, tem-se um $\mathrm{V}$ liberto resultante de um ato poético-político de confrontação.

Abstract
That article examines the visual poem "Man \&
Woman," by Max Martin, on theoretical per- 
spective linked to the calligraphy and the study of the form (Gestalt) that was studied by Haroldo de Campos, Julio Plaza and Décio Pignatari, authors that postulate that the dialogs between poetry and visual. "Man \& Woman" put the questions about the limits of the word (verb) and the "extension" of the graphic space of the poem through metalanguage. On second part, it has an essay reading of poems by Max Martins with the aim of establishing the relationship between word, image and thought.

Keywords: Max Martins; word; image; thought.

\section{REFERÊNCIAS}

BARTHES, Roland. O prazer do texto. Trad. J. Guinsburg. São Paulo: Perspectiva, 1987.

BOGÉA, José A. Abc do poeta Max Martins. Belém. Editora Universitária UFPA, 1992.

BATAILLE, Georges. Historia del ojo. Traducido por Margo Glantz. México D.F.: Ediciones Coyoacán, 1994.

BATAILLE, Georges. O erotismo. Trad. Cláudia Fares. São Paulo: Arx, 2004.

CAMPOS, Augusto. Poesia sempre. Ano 12. Número 19. Brasília: Mec, 2004.

CAMPOS, Augusto e HAROLDO de, e Décio PIGNATARI. Teoria da Poesia Concreta: textos críticos e manifestos. 1950-60. 2. ed. São Paulo: Livraria Duas Cidades, 1975.

CAMPOS, Haroldo de. A arte no horizonte do provável e outros ensaios. São Paulo: Perspectiva, 1977.

CAMPOS, Haroldo de. Ideograma. Lógica, Poesia, Linguagem. São Paulo, Perspectiva - Edusp, 2000.

COELHO, Marinilce Oliveira. O Grupo dos Novos: memórias literárias de Belém do Pará. Belém: EDUFPA: UNAMAZ, 2005.

LEMINSKI, Paulo. Matsuó Bashô. São Paulo: Brasiliense, 1983.

MARTINS, Max. Não para consolar: poesia completa. Belém: CEJUP, 1992.

NUNES, Benedito. Max Martins - Mestre-Aprendiz. In: MARTINS, Max. Não para consolar: poemas reunidos 1952 - 1992. Belém: CEJUP, 1992.

NUNES, B. Max Martins, mestre-aprendiz. In: Asas da Palavra. Revista da Graduação em Letras. Belém: Unama, v.5, n.11, 2000.

PIGNATARI, Décio. O que é comunicação poética. São Paulo: Brasiliense, 1987. 
PLAZA, Julio. Tradução intersemiótica. 3. ed. São Paulo: Perspectiva, 2008.

POUND, Ezra. ABC da literatura. (Org). CAMPOS, Augusto \& PAES, José Paulo. 11. ed. São Paulo: Cultrix, 2006.

Site consultado: http://farm3.static.flickr.com/2329/233636 4800_7d6f0cbc47.jpg 